\title{
The Patriarchal Palace at Constantinople in the seventh century: locating the Thomaites and the Makron
}

Article

Accepted Version

Dark, K. and Kostenec, J. (2014) The Patriarchal Palace at Constantinople in the seventh century: locating the Thomaites and the Makron. Jahrbuch der Österreichischen Byzantinistik, 64. pp. 33-40. ISSN 1810-536X doi:

https://doi.org/10.1553/joeb64s33 Available at https://centaur.reading.ac.uk/38515/

It is advisable to refer to the publisher's version if you intend to cite from the work. See Guidance on citing.

To link to this article DOI: http://dx.doi.org/10.1553/joeb64s33

Publisher: Österreichische Akademie der Wissenschaften, Vienna

All outputs in CentAUR are protected by Intellectual Property Rights law, including copyright law. Copyright and IPR is retained by the creators or other copyright holders. Terms and conditions for use of this material are defined in the End User Agreement.

www.reading.ac.uk/centaur 
Central Archive at the University of Reading

Reading's research outputs online 
Ken Dark - Jan Kostenec

\title{
The Patriarchal Palace at Constantinople in the Seventh Century: Locating the Thomaites and the Makron
}

\author{
With 7 figures
}

\begin{abstract}
New archaeological evidence suggests that the important patriarchal buildings called the Thomaites and Makron were immediately south-west of the sixth-century church of Hagia Sophia, rather than to its north-east as usually supposed. These structures were built in the sixth-century, suggesting only limited rebuilding of the Patriarchate by patriarch Thomas in the early seventh century.
\end{abstract}

In this paper, we will try to solve a key topographical problem concerning the seventh-century patriarchal structures (Patriarchate) that stood immediately south of the sixth-century church of Hagia Sophia. To do this, we will combine textual evidence with archaeological information from our own work at Hagia Sophia. The latter began in 2004 at the south-west corner of the standing building, where traces of the Patriarchate have survived best. Since then, we have paid a particular attention to this part of the site, as it is a crucial to understanding the whole of the Late Antique complex, the subject of our archaeological project. In this way our work at Hagia Sophia contrasts with previous studies, which have focused on the sixth-century church as an isolated monument. ${ }^{1}$

It may be useful first to summarise our results concerning the archaeology of Patriarchate. ${ }^{2}$ Removal in the 1990s of the recent exterior plaster at the south-west corner of

\footnotetext{
${ }^{1}$ For summaries of the work of the project see K. DARK - J. KOSTENEC, A new archaeological study of Hagia Sophia, Istanbul, in: Proceedings of the 22nd International Congress of Byzantine Studies, Sofia, 22-27 August 2011, III/1. Sofia 2011, 213-237; K. DARK - J. KOSTENEC, The Hagia Sophia project, Istanbul. Bulletin of British Byzantine Studies 37 (2011) 48-68; IIDEM, Paul the Silentiary's description of Hagia Sophia in the light of new archaeological evidence. BSl 69/3 (2011) 88-105; IIDEM, The Hagia Sophia project, Istanbul: report on the 2009 season. Bulletin of British Byzantine Studies 36 (2010) 40-49; IIDEM, The Hagia Sophia project, Istanbul, 2004-8. Bulletin of British Byzantine Studies 35 (2009) 56-68; IIDEM, The Byzantine patriarchate in Constantinople and the baptistery of the church of Hagia Sophia. Architectura 36 (2006) 113-130.

${ }^{2}$ Removal of the modern plaster in the early 1990s was reported by the Ahunbays, who were the first to recognise the existence of this demolished vaulted room south-west of the sixth-century church. However, they did not proceed further in reconstructing its possible appearance and architectural details in their short report on the restoration work (see M. AHUNBAY - Z. AHUnBAY, Conservation of Hagia Sophia in Istanbul, in: More than two thousand years in the history of architecture. Safeguarding the structures of our architectural heritage. Proceedings of the International congress Uniesco-Icomos. Paris 2003, 80-82, especially 81). We have discussed this contribution by the Ahunbays previously in DARK - KOSTENEC, The Byzantine patriarchate in Constantinople and the baptistery of the church of Hagia Sophia 118-119. For the results of our study concerning the Patriarchate see IIDEM, A new archaeological study of Hagia Sophia, Istanbul 220-222; IIDEM, Paul the Silentiary's description of Hagia Sophia 92-93 and 96, fig. 2; IIDEM, The Hagia Sophia project, Istanbul:
} 
the church enabled us to identify structural evidence that permits the reconstruction of a large, rectangular, structure, (called by us 'the Large Hall') extending from the standing building into the area of the Ottoman ablution-fountains (figs. 1 and 2). The vaulting of the Large Hall was divided into three bays, of which those to the north and south were barrelvaulted and the middle bay covered either by a cross-vault or, more likely, by a shallow dome. Three narrow window openings, of which traces remain, in the east wall, lit this central bay, and three large round-headed openings in the north wall originally formed a monumental triple arcade of what was probably its principal entrance (fig. 2). Furthermore, a - now blocked - marble doorway in the west wall of the southernmost of the three small rooms flanking the large room above the south-west vestibule of the church (fig. 2, no. 6) opened onto the roof of the Large Hall, which was presumably, at least partly, flat. This roof could, then, have served as a terrace.

To the north of the Large Hall there is another high, barrel-vaulted, space (figs. 2 and 3). This is usually identified as the horologion, but as it originally opened into the Large Hall through the triple arcade mentioned above (and communicated with the south-west vestibule of the church) it is more likely to have been built as an antechamber to the Large Hall. The walls of this antechamber are constructed of pure brick masonry with occasional courses of stone, a constructional style paralleled in other sixth-century buildings in Istanbul. Moreover, several in situ Byzantine bricks in this room bear two-line stamps identical to those recorded by earlier scholars in the original structure of the Justinianic church, suggesting that both this structure and the Large Hall were constructed as part of the same building programme as Justinian's church. A vaulted substructure of post-sixth-century Byzantine date was built underneath the antechamber after the disuse of this monumental entrance, requiring the overlying floor to be raised by about $2.2 \mathrm{~m}$ (previously we had thought it was about $1.5 \mathrm{~m}$ but new evidence from fieldwork in 2014 showed this observation to be incorrect) (fig. 4).

The Large Hall had internal dimensions of about $10 \mathrm{~m}$ by $20 \mathrm{~m}$, larger than the room above the south-west vestibule (fig. 2), usually identified as the Large Secreton of the Patriarchate, built during the reign of Justin II. $^{3}$ The plan, scale and position of the Large Hall suggests that it was an important reception- or meeting- room and we have suggested elsewhere that it might have been the secretarium where 168 bishops gathered during the

report on the 2009 season 43-45, 47 and fig. 3; IIDEM, The Hagia Sophia project, Istanbul, 2004-8, 62; IIDEM, Byzantine patriarchate in Constantinople and the baptistery of the church of Hagia Sophia 120-123.

3 C. MANGO, The Brazen House: a study of the vestibule of the imperial palace of Constantinople. Copenhagen 1959, 52-53; R. CORMACK - E.J.W. HAWKINS, The mosaics of Saint Sophia at Istanbul: the rooms above the southwest vestibule and ramp. DOP 31 (1977) 75-251. 
Second Council of Constantinople in 553, and the room in which Paul the Silentiary recited his famous Ekphrasis of the church early in $563 .^{4}$

The Large Hall was not a free-standing structure, but just part of an extensive block of rooms adjoining the south wing of the Justinianic atrium (figs. 1 and 2). In addition to the Large Hall, this included smaller rooms of which two stories survive (the third storey has been completely demolished), and a long, east-west, vaulted room above the east end of the atrium colonnade, preceeded on the east by a smaller cross-vaulted room above the exonarthex (fig. 5). While the smaller rooms may be dated on constructional grounds to the sixth century, the long east-west room and the cross-vaulted room are later additions. The south wall of this long room is of double thickness, its outer part originally forming the north façade of the sixth-century structure (and so, if we are correct, of the Patriarchate), and containing large round-headed openings, later blocked. The inner part of the wall, the north wall of the same room and its vaulting, are all probably later, being constructed of small, postsixth-century, brick. Similar bricks are also used in the small cross-vaulted room above the exonarthex. The long room still preserves unusual, but probably Byzantine-period, decoration: a pavement of small square stone slabs, and ceramic tiles showing wave-like decoration (unfortunately not in situ), which may have been used as wall-revetment.

Consequently, the sixth-century Patriarchate may be reconstructed in some detail for the first time using archaeological evidence. This complex (figs. 1 and 2) included the Large Hall with its antechamber, the rooms between this and the atrium, rooms above the south-west vestibule and ramp, and probably also a smaller centrally-planned reception room to its east: the octagon-in-square building usually identified as a purpose-built baptistery. Of course,

\footnotetext{
4 The Second Council of Constantinople: Sacrorum conciliorum nova et amplissima collectio XXXI/9, ed. G.D. MANSI. Florence 1692 - 1769, 173. The standard edition of Paul the Silentiary's Ekphrasis of Hagia Sophia is Johannes von Gaza und Paulus Silentiarius, Kunstbeschreibungen justinianischer Zeit, ed. P. FRIEDLÄNDER. Leipzig - Berlin 1912, 227-256. Although the first prologue of Paul's poem, a panegyric addressed to Justinian I, was delivered in the Great Palace, the poet and his audience then moved to the Patriarchate, where the remainder of the poem was recited. The lemma between the two prologues (between 11. 80 and 81) mentions the palation (the Great Palace of the Emperors) and the episkopeion (the Patriarchate). The ekphrasis of the ambo was also recited in the Patriarchate (in the patriarcheion, as is clear from the lemma at the beginning of the ekphrasis). See also DARK-
} KosTENEC, The Hagia Sophia project, Istanbul: report on the 2009 season 43-44 and IDEM, Paul the Silentiary's description of Hagia Sophia in the light of new archaeological evidence 90-94. 
there may have been further rooms to the west and east of these, outside the area in which structural evidence is available without further excavation.

Given their location, these structures probably formed the core, or at least part of the core, of the Patriarchate. Although one could argue for a more complicated sequence, all may be accommodated within two building programmes: one in the Justinianic period, alongside the construction of the church; the other under Justin II. Both programmes are textually attested, even if texts provide imprecise information about what they involved. Thus, it may be possible to reconstruct important structures from the Justinianic Patriarchal complex and to identify how these were modified later in the sixth century.

Interestingly, while Byzantine texts say very little about the Patriarchate in the sixth century, they provide much information about subsequent modifications and additions. ${ }^{5}$ However, these textually-attested developments remain difficult to identify archaeologically. An especially enigmatic part of the seventh-century Patriarchate is that allegedly built by the patriarch Thomas (607-610), known as the Thomaites. ${ }^{6}$

The Thomaites was apparently a large structure, comprising a hall of outstanding length - called the Makron -and several smaller rooms. The Patriarchal library was located in a vaulted space beneath the Thomaites, and the building had an important role in Late Byzantine imperial coronation ceremonies, when the new emperor was proclaimed by elevation on a shield at the Thomaites in front of local inhabitants and the army, who assembled in the Augustaion, indicating that the Thomaites was to the south of the sixthcentury church. This ceremony took place in the upper part of the Makron, the balustrade or railing of which was temporarily removed in order to make the emperor more visible to those gathered in the Augustaion. Textual sources also imply that the Thomaites communicated with the church at least on the level of the galleries. Perhaps because of its use for synods, the hall of the Thomaites seems to be identical with the Synodoi - as its name implies, a place where synods were held. ${ }^{7}$

\footnotetext{
${ }^{5}$ See especially, R. JANIN, Le palais patriarcal de Constantinople Byzantine. REB 20 (1962) 131-155.

${ }^{6}$ Nicephorus Callistou, Ecclesiastic History XVIII 44 (PG 147, 417).

7 On the Thomaites see especially R. GuILLAND, Études sur Constantinople byzantine. Le Thomaïtès et le Patriarcat. JÖBG 5 (1956) 27-40 and JANIN, Le palais patriarcal de Constantinople Byzantine 144-149, with references to the relevant textual sources.
} 
Although scholars unanimously situate the Thomaites on the east side of the Augustaion (fig. 6), ${ }^{8}$ the evidence for this is weaker than it may initially seem, being based only on one passage in De Cerimoniis, describing the promotion of the zoste patrikia. ${ }^{9}$ This says that the zoste patrikia went from the east part of the church (near the sanctuary) to the metatorion of the Thomaites, situated on the gallery level of the church. She then continued through elevated passages to the hall of the Magnaura in the north part of the imperial palace. On analogy with relevant chapters in De Cerimoniis, it is supposed that she ascended the access ramp at the southeast corner of the church and, after having spent some time in the metatorion of the Thomaites, left the gallery of the church via the wooden spiral staircase situated on the east façade of the church. The lower end of the latter opened into the upper storey of the two-storied portico leading southeast from the church to the imperial palace. ${ }^{10}$ As both the access ramp and the wooden staircase were apparently on the south-east corner of the church, it might be supposed that the metatorion of the patriarchs - opening off the south gallery - was also in this location. If so, the Thomaites was connected to the church near its south-east corner and extended southwards along the east side of the Augustaion. ${ }^{11}$ However, such an interpretation of the text in De Cerimoniis is far from certain.

It is not stated in the text which way the zoste patrikia went to the gallery of the church. Although she may have ascended by the south-east ramp, it is equally likely that she used the south-west ramp, or even the staircase in the south-west buttress. The south-west ramp served in the post-Justinianic period as one of the access ways to the Patriarchate and might be the most likely of these. ${ }^{12}$ Its upper storey not only opened to the gallery of the church but also provided direct access to the rooms on the top of the ramp and the adjacent church vestibule, which, as already mentioned, were part of the Patriarchate. This could be

\footnotetext{
${ }^{8}$ GuILLAnd, Le Thomaïtès et le Patriarcat 29-32; MANGO, The Brazen House 52-53, 94-96; JANIN, Le palais patriarcal de Constantinople Byzantine 146-149 and plan on 154; A. BERGER, Untersuchungen zu den Patria Konstantinoupoleos (Poikila Byzantina 8). Bonn 1988, 262; IDEM, Die Senate von Konstantinopel. Boreas 18 (1995) 134-135 and fig. 1; N.ASUTAY-EFFENBERGER - A.EFFENBERGER, Zur Kirche auf einem Kupferstich von Gugas Inciciyan und zum Standort der Chalke-Kirche BZ 97 (2004) 51-94.

${ }^{9}$ De Cerimoniis I 50, 260, ed. J.J. REISKE, Constantini Porphyrogeniti imperatoris De cerimoniis aulae byzantinae libri duo. Bonn 1829.

${ }^{10}$ De Cerimoniis I 22, 125; I 28, 157; II 10, 548; II 38, 635 (REISKE); GuILLAND, Le Thomaïtès et le Patriarcat 29-31; MANGO, The Brazen House 87-92. For the Magnaura see J. KostenEC, Magnaura, in: Encyclopedia of Hellenic World: http://constantinople.ehw.gr/forms/fLemma.aspx?lemmaId=12436 (accessed on 4 July 2014); IDEM, Observations on the Great Palace at Constantinople: The Sanctuaries of the Archangel Michael, the Daphne Palace, and the Magnaura. Reading Medieval Studies 31 (2005) 42-46; BERGER, Die Senate von Konstantinopel135-142 and R. GUILLAND, La Magnaure. EEBS 27 (1964) 63-74.

${ }^{11}$ GuILland, Le Thomaïtès et le Patriarcat 29-32; JANIN, Le palais patriarcal de Constantinople Byzantine 145146.

${ }^{12}$ MANGO, The Brazen House 53-54; CORMACK - HAwKINS, The mosaics of Saint Sophia at Istanbul: the rooms above the southwest vestibule and ramp 247-251.
} 
where the Patriarchal metatorion was situated. ${ }^{13}$ Even if the zoste patrikia went to the gallery via the south-east ramp, it is not clear from any surviving text whether the Patriarchal metatorion was nearer to the east or west end of the south gallery. It was unnecessary to pass through this metatorion on the way from the ground-floor of the church to its south gallery through the south-east ramp: on the 'Feast of the Triumph of Orthodoxy', when both the emperor and the patriarch ascended this ramp in order to reach the gallery, the patriarchal metatorion is not mentioned. ${ }^{14}$

Any physical evidence of a possible connection of the south-east corner of the gallery and the Thomaites/Makron has disappeared. At the south-east corner of the church there is a bulky buttress, projecting south from the south façade. This buttress, and also another similar structure to its west, may be reasonably ascribed on constructional grounds to the emperor Andronicus II (1282-1328), who is said to have erected outer 'pyramidal' structures in 1317 in order to stabilise the church. ${ }^{15}$ Hypothetically, the south-east buttress could have replaced part of the Thomaites, but as today the relevant walls are veneered with marble and plastered no traces exist of a door.

Another possibility is that the Thomaites/Makron could have connected to the south gallery where the 'pyramidal' buttress is located. But even if the (probably Late Byzantine) buttress occupies the site of an earlier structure, it could not communicate directly with the church on the gallery level. The Byzantine narrow spiral staircase inside the Justinianic buttress pier is still intact but there is no evidence of a door on the south side of the buttress pier on the gallery level. The Thomaites/Makron is, therefore, unlikely to have been in front of the south-east buttress pier of the church.

${ }^{13}$ A - now disused - narrow staircase connecting the main stairway of the access ramp leads to the south gallery of the church, the small room at its top (originally a lantern tower of the Justinianic ramp), termed by Cormack and Hawkins the 'Alcove', see CORMACK - HAWKINS, The mosaics of Saint Sophia at Istanbul: the rooms above the southwest vestibule and ramp 195. Although these scholars mentioned the possibility that the 'Alcove' may have served as a metatorion, they finally rejected this and interpreted it instead as a ceremonial way between the Large and Small Secreton, see CORMACK - HAWKINS, The mosaics of Saint Sophia at Istanbul: the rooms above the southwest vestibule and ramp 247. However, the 'Alcove' is a good candidate for the patriarchal metatorion because it was accessible from the gallery of the church via the hall above the vestibule and also from the access ramp, which connected the gallery level with both the groundfloor of the church and the exterior.

14 De Cerimoniis I, 28, 159-160 (REISKE).

${ }^{15}$ R.J. MAINSTONE, Hagia Sophia: architecture, structure and liturgy of Justinian's Great Church. London 1988, 102-105. 
All of these attempts to identify the location of the Thomaites are based on reconstructions of the Augustaion as aligned with the east wall of the church. Nevertheless, Stichel has recently plausibly identified the colossal Corinthian columns mentioned by several travellers between the early fifteenth and mid-sixteenth centuries with the columns of the porch of Justinian's Senate, which Procopius tells us was on the east side of the forum. ${ }^{16}$ This places the east side of the forum between the approximate centre of the south side of the baptistery and the west side of the mausoleum of Selim II (fig. 7). Moreover, he suggests that the disused Justinianic Senate may have become part of the Patriarchate in the early seventh century and it was this structure that was subsequently known as the Thomaites. ${ }^{17}$ Stichel's reconstruction implies that the porch of the Senate was rebuilt after the building became part of the Patriarchate. The columns of the porch would have supported the upper storey of the Makron, which connected to the gallery of the church.

Stichel uses this evidence to set out two alternative reconstructions of the size of the Augustaion. Only the bigger of these (fig. 7b) would be in accord with what texts tell us about the Makron. It is described as a long, north-south, structure, the north end of which adjoined the south gallery of the church while the southernmost part overlooked the Augustaion. If the Makron had been aligned with the porch of the Senate/Thomaites (as Stichel reconstructed this) it would, therefore, have been attached to the church in the centre of its south façade, where the Middle Buttress is located today.

The south part of this buttress appears to be Ottoman and only the north part, the interior of which has three levels, is earlier. The exterior of the buttress is faced with stone and partly plastered, but where the masonry is exposed in the interior of the buttress it is possible to recognise that its walls and sloping barrel-vault are the result of a Late Byzantine or Early Ottoman rebuilding. They are comprised of a single course of stone alternating with one or two courses of brick, but a narrow arch immediately in front of the façade of the sixthcentury church is built of pure brick, and may be earlier. Although this buttress communicates with the gallery level through a marble door, it is impossible to determine how far south the earliest phase of the structure reached and, therefore, whether the buttress could, even hypothetically, have been associated with the Makron.

\footnotetext{
${ }^{16}$ R. STICHEL, Sechs kolossale Säulen nahe der Hagia Sophia und die Curia Justinians am Augusteion in Konstantinopel. Architectura 30 (2000) 1-25.

${ }^{17}$ STICHEL, Sechs kolossale Säulen nahe der Hagia Sophia 24.
} 
Stichel's smaller reconstruction of the Augustaion (fig. 7a) has the Makron terminating at the baptistery rather than on the south side of the church, which can be ruledout as it contradicts the textual evidence. The only remaining possibility that allows a connection between the gallery and porch of the Senate (if it was located where Stichel places it) is if the porch and Makron were aligned with the south-west buttress and the east side of the baptistery. Nevertheless, this is also unlikely, because the outer buttress can be shown never to have continued further to the south than at present.

Thus, Stichel's proposal that the porch of the Senate, identified by him as part of the Thomaites, was aligned with the west side of the mausoleum of Selim II seems most likely. This might allow a connection between the west façade of the Thomaites, overlooking the Augustaion, and the sixth-century church by means of a long, north-south, hall or corridor the Makron - at the point where there is a door on the gallery level in the south wall of the church. This door leads today to the south middle buttress, but that was added later.

However, travellers in the sixteenth century and earlier, including Ruy Gonzales de Clavijo (1403) and Buondelmonti (1420), describe the colossal columns at the Augustaion as free-standing, without the ruins of a building associated with them. ${ }^{18}$ This implies that by the beginning of the fifteenth century (at latest) the building to which the columns belonged probably the Senate, as Stichel argues - was demolished to such an extent that it had either passed from view or its ruins were considered too slight to mention. If this building was the Thomaites, one would expect more to survive, as according to Pseudo-Codinus it was used in imperial coronations as late as the mid- or late -fourteenth century. ${ }^{19}$

18 Buondelmonti, 53-4 (ed. I. SIEBERT - M. PLASSMANN - A. EFFENBERGER - F. RIJKERS, Cristoforo Buondelmonti, Liber insularum archipelargi. Wiesbanden 2005). See also T. THOMOV, New Information about Cristoforo Buondelmonti's Drawings of Constantinople. Byzantion 66/2(1996) 431-453; I.R. MANNERS, Constructing the Image of a City: The representation of Constantinople in Cristopher Buondelmonti's Liber Insularum Archipelagi. Annual of the Association of American Geographers 87/1 (1997) 72-102 and A.B. YALÇIN, XV. yy.' da bir italyan gezgin: Cristoforo Buondelmonti ve Konstantinopolis, in: Istanbul Üniversitesi 550. Y1l Uluslararası Bizans ve Osmanlı Sempozyumu (XV. yüzyıl): 30 - 31 Mayıs 2003 / 550th Anniversary of the Istanbul University International Byzantine and Ottoman Symposium (XVth Century) (ed. S. ATASOY). Istanbul 2004, 371-390. Clavijo, 37 (ed. F. LÓPEZ ESTRADA, Ruy González de Clavijo, La embajada a Tamorlán. Madrid 1999).

${ }^{19}$ R. MACRIDES - J.A. MUNITIZ - D. ANGELOV, Pseudo-Kodinos and the Constantinopolitan Court: Offices and Ceremonies (Birmingham Byzantine and Ottoman Studies 15). Aldershot-Farnham or Burlington 2013, 214-217. For the coronation of Michael IX in 1294 see Pachymeres III 219-221, ed. A. 
Clavijo says that he was informed by the local people that the huge columns by the Augustaion supported a palace in which the patriarchs and clergy held meetings, but it is apparent from his account that no remains of such a building were preserved at that time. The popular association of the columns with the Patriarchate can be explained by the fact that the Augustaion in the Late Byzantine period was no longer regarded as an separate forum but as a courtyard of Hagia Sophia. ${ }^{20}$ Consequently, although the association of the monumental columns with the Justinianic Senate is probable, the identification of the Senate with the Thomaites is unlikely. If so, this re-opens the question of what happened to the Senate House after the sixth century, when it disappears from textual sources. It also allows the Thomaites and Makron to be sought elsewhere on the south side of Hagia Sophia.

A careful reading of two passages from Choniates' chronicle reveals that the Thomaites is more likely to have stood near the south-west corner of the sixth-century church than on the east side of the Augustaion. The first of these is the account of the battle between partisans of the kaisarissa Maria and loyal imperial troops around the Augustaion in $1182 .{ }^{21}$ We are not only told of men discharging stones and arrows from the upper part of the hall (andronos) called the Makron, that part of the Thomaites projecting south in direction of the Augustaion - probably on a north-south aligment - but also that the kaisar made a speech to the defenders of the church, who had fled from the Augustaion to the south-west vestibule, from 'a raised bench' located at the Makron. ${ }^{22}$ This implies that the Makron stood at the south-west corner of the sixth-century church, near the south-west vestibule.

FAILLER, Georges Pachymérès, Relations historiques (CFHB 24/3). Paris 1999 and GUILLAND, Le Thomaïtès et le Patriarcat 27-29.

${ }^{20}$ R. GuILLAND, L'Augustéon. EEBS 18 (1948) 161-164.

${ }^{21}$ Choniates I, 234-41, esp. 236-239 (ed. I.A. VAN DIETEN, Nicetae Choniatae Historia [CFHB 11]. Berlin 1975); C.CUPANE, La "guerra civile" della primavera 1181 nel racconto di Niceta Coniate e Eustazio di Tessalonica: narratologia historiae ancilla? JŐB 47 (1997) 179-194; J.-I. VAN DIETEN, Eustathius von thessaloniki und niketas choniates über das Geschehen im Jahre nach dem tod manuels i. Komnenos JÖB 49 (1999) 101-112.

22 Choniates tells us that the partisans of the kaisarissa Maria were pushed out of the Augustaion by the imperial troops and fled to the pronaos/proskenion of the church (also called the protekdikeion - JANIN, Le palais patriarcal de Constantinople Byzantine 150), which was decorated with a mosaic of the archangel Michael. The pronaos of the archangel Michael is also mentioned by Russian travellers in the Late Byzantine period and is generally identified either with the south-west vestibule of the church, which in the course of the Byzantine period became the main entrance to the church, or (perhaps more likely) with a 
The second passage from Choniates describes the great fire of 1203 that ravaged the city shortly before its fall. ${ }^{23}$ According to Choniates, the fire set by the Latins in the area of the Prosphorion and Neorion harbours on the Golden Horn spread southwest along the street leading uphill to the city centre, where it also endangered Hagia Sophia. This fire damaged all buildings between the Milion and the Makron of the Thomaites and spread southwards to the Sea of Marmara, partly damaging the Hippodrome. The course of the fire (and so location of the Makron and Thomaites) was, therefore, west of the Augustaion, which seems to have avoided any damage (for the location of the Milion, Augustaion and the Hippodrome see fig. 6).

Re-locating the Thomaites at the south-west corner of the church has important implications not only for the topography of the Patriarchate as a whole but also for its structural history. As discussed above, we have identified Patriarchal structures south-west of the sixth-century church (figs. 1 and 2): the Large Hall (which had an, at least partly flat, roof serving as a terrace accessible from the rooms above the south-west vestibule of the church), three stories of smaller rooms adjacent to it, and further rooms on the top of the south-west vestibule and ramp connecting these structures with the south gallery of the church. ${ }^{24}$ These features are consistent with the picture of the Thomaites gained from textual sources. The only location where the Makron could be situated to account for all the details mentioned in Choniates' description is exactly where the Large Hall once stood. However, if the Large Hall is the Makron, patriarch Thomas did not build a completely new part of the Patriarchate, but restored (and possibly modified) buildings constructed under Justinian I and Justin II. In other words, there was no major seventh-century phase in the construction of the Patriarchate.

supposed ancillary area of this vestibule, see G.P. MAJESKA, Russian Travellers to Constantinople in the Fourteenth and Fifteenth Centuries. Washington DC 1984, 202-203.

${ }^{23}$ Choniates I, 554-555 (VAN DIETEN). Choniates' account of the fire suggests that the Thomaites and the Makron were not seriously damaged. This seems to be supported by the fact that the Makron was used in the coronation ceremonies in the Late Byzantine period (see above).

${ }^{24}$ Our examination of the west wall of the range of three small rooms flanking the hall above the south-west vestibule (generally identified as the Large Secreton) revealed that the existing wall in the middle room is not original and that this room opened into further spaces to its west, which formed the third storey of the part of the building between the Large Hall and the atrium. That the roof of the Large Hall was, at least partly, flat further supports the identification of the Large Hall as the Makron of the Thomaites, given the descriptions of Late Byzantine coronation ceremonies during which the new emperor was elevated on shield in front of the people gathered in the Augustaion (see above and n. 19). 
At least some of the structural alterations to the Large Hall might tentatively be dated to this seventh-century programme of refurbishment. These include the separation of the hall from its antechamber by the removal of the supports of the triple arcade and the blocking of the openings beneath it; the construction of a cross-vaulted substructure beneath the antechanber (and probably also beneath the hall, as there is a blocked opening in the middle of the south side of the substructure); the associated raising of the floor level by about $2.2 \mathrm{~m}$, and the addition of the long room and the cross-vaulted room above the atrium and the exonarthex respectively. The construction of the vaulted substructure (fig. 4) brings to mind the Patriarchal library situated in a vaulted space beneath the Thomaites, although any such identification can, of course, be only tentative. ${ }^{25}$ Likewise, it may be that the long room above the south wing of the atrium and the cross-vaulted room above the exonarthex (figs. 2 and 5) may be associated with the Patriarchal rooms that directly overlooked the atrium during the reign of Justinian II (685-95, 705-11) and may have been also built by the patriarch Thomas. ${ }^{26}$

On this basis, we propose that Patriarchal buildings which we have identified in our work southwest of the sixth-century church are those known in the seventh century and later as the Thomaites and Makron. The re-building of the Patriarchate by patriarch Thomas was, therefore, a more limited programme of construction than often assumed.

\footnotetext{
25 Theophanes, 260 (ed. C. DE BOOR, Theophanis Chronographia. Leipzig 1883/85). The library burnt down in 791, but was soon restored, judging from Theophanes' refererence to it in the reign of Theophilos. If the construction of the vaulted substructure beneath the antechamber of the Large Hall (and probably beneath the hall itself also) can be associated with the Patriarchal library, which existed before 791, then both it and the replacement of the triple arcade between the antechamber and the hall cannot be associated with damage caused by that fire.

26 Theophanes, 369 (DE BOOR); GUILLAND, Le Thomaïtès et le Patriarcat 33.
} 